\title{
The Effects of the ECB's Unconventional Monetary Policy on the Non-Euro Area EU Member States
}

\author{
Silvia Trifonova ${ }^{1}$, Atanas Atanasov $^{2},{\text { Svilen } \mathrm{Kolev}^{3}}^{3}$
}

\begin{abstract}
:
The paper examines the unconventional monetary policy programs and measures, implemented by the European Central Bank (ECB). The research is focused on covering their effects on the non-Euro Area Member States of the European Union (EU). The main purpose of the paper is to conduct an econometric study on the effects of the ECB's nonstandard measures on the government bond yields of the countries, part of the EU, but outside the Eurozone, through the interest rate channel of the monetary policy transmission mechanism.
\end{abstract}

The study is dedicated to the empirical study on the dynamics and the relations between the key interest rates and the government bond yields of Bulgaria, Denmark, United Kingdom, Poland, Romania, Croatia, Czech Republic and Sweden. The observed period spreads from January 2010 to December 2016, with the use of monthly data.

The aggregated results from the constructed econometric models for the non-Euro area EU Member States show that between 95\% and 98,5\% of the changes in the government bond yield can be explained by the changes in the levels of the Euro Over Night Index Average(EONIA) - an interest rate factor, and by the time - the second factor in the model.

The results also show that at EONIA fixed rates the yield on the long-term government bonds can vary from -0,025 percentage points to -0,068 percentage points monthly.

Conclusions and proposals are made, concerning the interest rates in the Eurozone and in the EU, in the context of the unconventional monetary policy, conducted by the ECB - one of the world's major central banks.

Keywords: Unconventional monetary policy, quantitative easing, central banks, negative interest rates, econometric modeling

JEL Classification Codes: E40, E52, E58, F30, G15, F42, C5

\footnotetext{
${ }^{1}$ Assoc. Prof. PhD, Department of Finance, Finance and Accountancy Faculty, University of National and World Economy, Sofia

${ }^{2}$ Chief Assist. PhD, Statistics and Econometrics Department, Applied Informatics and Statistics Faculty, University of National and World Economy - Sofia

${ }^{3}$ PhD Candidate, Department of Finance, Finance and Accountancy Faculty, University of National and World Economy - Sofia
} 


\section{Introduction}

The paper covers the effects of the unconventional monetary policy programs and measures, implemented by the European Central Bank (ECB), on the non-Euro area EU Member States. The main purpose of the paper is to conduct an econometric study on the effects of the ECB's non-standard measures on the government bond yields of the countries, part of the EU, but outside the Eurozone, through the interest rate channel of the monetary policy transmission mechanism. The object is the unconventional monetary policy of the ECB. The subject is the change of central banks' base interest rates and its influence on government bond yields in the nonEuro area EU Member States. The research covers 9 countries and the 2010-2016 period.

The main thesis of the proposed paper is that the unconventional monetary policy affects the government bond yields, with a moderate transmission effect through the interest rate channel. The main scientific area of the paper is monetary theory and monetary policy. The scope extends to the field of international finance, including international financial organizations, currency exchange regimes, international financial markets. The methodology, applied in the analysis, includes:

- Conducting an empirical study regarding the base interest rates in the Euro area and the government bond yields of the countries outside the single currency union, but part of the EU;

- Comparative analysis, used for outlining the similarities and differences between the effects on the government bond yields from the base interest rates changes;

- Applying a systematic approach in analyzing the interest rates and government bond yields of the non-Euro area EU Member States;

- Conducting an econometric modeling by using EViews statistical software for the empirical assessment of the impact of the interest rates transmission channel on the government bond yields of the analysed countries. The econometric model has the following view:

$Y_{t}=\beta_{0}+\beta_{1} X_{t}+\beta_{2} t+\varepsilon_{t}+\varepsilon_{t-1}+\varepsilon_{t-2}$

where

$Y_{t}$ (dependent variable) is the yield on long-term government bonds,

$X_{t}$ is the independent variable for the base interest rates,

$t$ is for the time as another independent variable,

$\varepsilon_{t}$ is for the residual component.

The assumed risk of error is $\alpha=0,05$.

- The use of the least squares method, conducting an autocorrelations test and assessment of the model;

- Applying of critical analysis about the effects from the unconventional monetary policy, implemented by the ECB. 


\section{Empirical study for identifying and assessing the impact of key interest rates changes on the government bond yields in the non-Euro area EU Member States}

This section is dedicated to the empirical analysis of the dynamics and the relations between the key interest rates and the bond yields, issued by the governments of the EU Member States, which are non-Euro area members - Bulgaria, Denmark, the United Kingdom, Poland, Romania, Croatia, the Czech Republic and Sweden. Accordingly, all nine non-Euro area EU Member States are covered in the analysis. The observation period is from January 2010 to December 2016, with the use of monthly data (towards the end of the respective month), respectively - the length of the time series is 84 terms. The yield on the long-term government securities of the non-Euro area EU Member States in the developed econometric model is presented as the dependent variable $Y_{t}$, and the factor variables are EONIA, denoted by $X_{t}$, and the time $\mathrm{t}$.

As it is known from the statistical literature, the use of the correlation analysis for studying the relationships between the time series, the so-called "false correlation" may arise. It arises from the fact that two-time series may have a similar development trend and a third-party factor may affect the government bond yields and the key interest rates, while between them there is no such a strong link as the ratio of correlation shows (for more information see Velitchkova (1981) ${ }^{4}$, Mishev and Goev $\left.(2010)^{5}\right)$. Therefore, to avoid the occurrence of a false correlation, in the econometric model for the relationship between the yield on government securities and the key interest rates, the time is included as an additional factor (Thalassinos et al., 2015a; 2015b; Cristea and Thalassinos, 2016; Thalassinos and Dafnos, 2015). The least squares method was used for modeling, autocorrelation testing was done, and assessment of the models for the respective countries, too. Information about the assessment of the models, done by the least squares method, and about the autocorrelation coefficients and autocorrelograms of the residual component is given country by country. General conclusions for the non-Euro area EU Member States are also presented in this section.

\section{Bulgaria}

The factor for the interest rates in the constructed econometric model for Bulgaria is the Base Interest Rate. The model was assessed by the least squares method and the results ${ }^{6}$ are as follows:

\footnotetext{
${ }^{4}$ Veltchkova, N., Statistical methods for studying and forecasting the development of socioeconomic phenomena, Science and Art, S., 1981.

${ }^{5}$ Mishev, G., V. Goev, Statistical analysis of time series, Avangard Prima, S., 2010.

${ }^{6}$ For more information, refer toTrifonova, S., Atanasov, At., Kolev, Sv., The Unconventional Monetary Policy of the World's Leading Central Banks and its Effects on Developed and
} 
Table 1. Results from the econometric model for Bulgaria

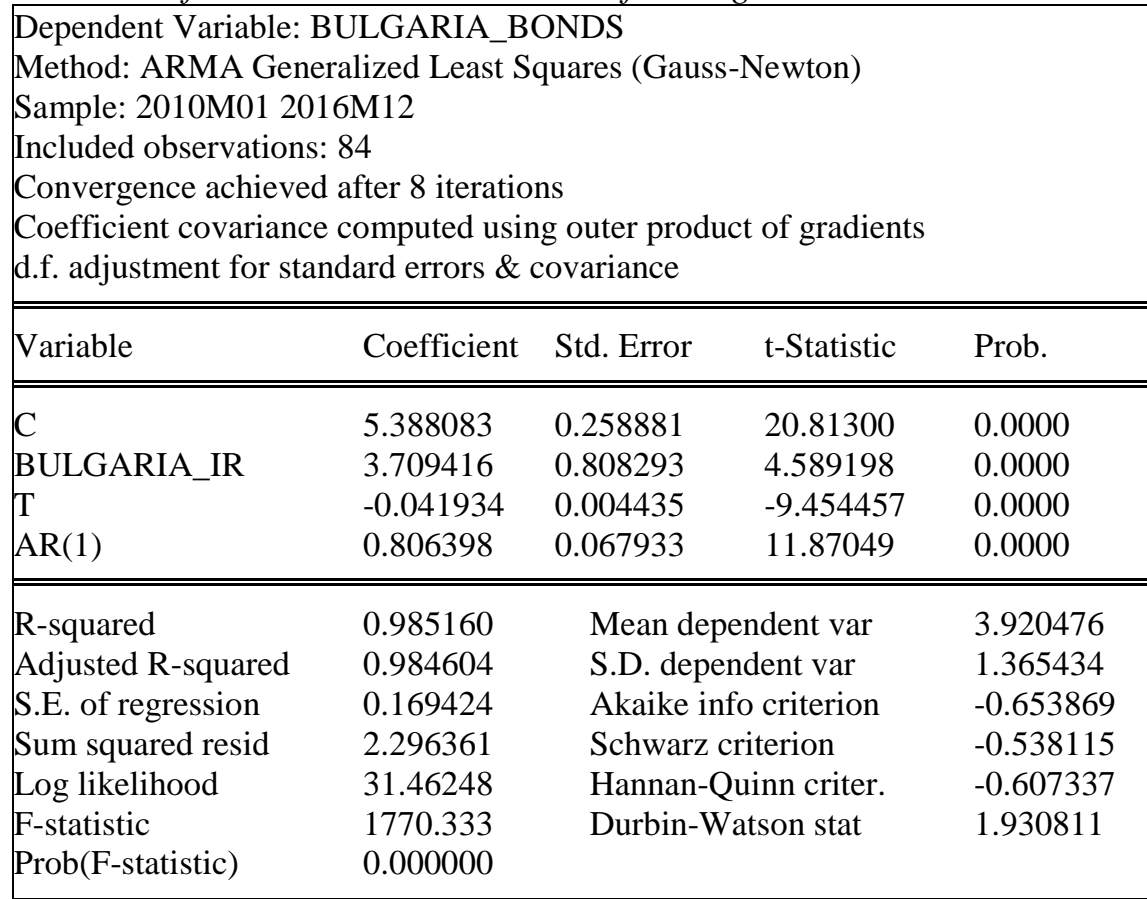

The results from the developed econometric model for Bulgaria show that the model is adequate. This is confirmed by the F-test-Prob (F-statistic) $<\alpha$, where $\alpha=0,05$. The model has a very high explanatory power $-\mathrm{R}^{2}=0,985$. This means that $98,5 \%$ of the interest rate changes of the long-term Bulgarian government bonds can be explained by changes in those factors. In addition, the two factors have a statistically significant impact since the level of significance (prob.) is lower than the assumed risk of error $\alpha$.

The assessed model has the following analytical view:

$\hat{Y}_{t}=5,39+3,7 . X_{t}-0,04 \cdot t+0,8 \cdot \varepsilon_{t-1}$

Since the parameters in front of the factors can be considered as statistically significant, they can be interpreted. From the obtained results, the following two conclusions can be made:

1. By increasing the Base Interest rate in Bulgaria by 0,1 percentage points (p.p.), the yield on the long-term bonds, issued by the Bulgarian government, ceteris paribus, will rise by 0,37 p.p.

2. At fixed levels of the Base Interest Rate each month the interest rate on the longterm securities of the Bulgarian government is expected to decrease by 0,04 p.p.

Developing Countries, including Bulgaria, collective monograph, Eudemonia Production, Sofia, 2017. 
In order to ensure the quality of the obtained results, the model was tested for the presence of autocorrelation in the residuals as well as for the type of residuals distribution.

Figure 1. Autocorrelogram of the residual component $\varepsilon_{t}$

Sample: $2010 \mathrm{M} 012016 \mathrm{M} 12$

Included observations: 84

Q-statistic probabilities adjusted for 1 ARMA term

\begin{tabular}{|c|c|c|c|c|c|c|}
\hline Autocorrelation & Partial Correlation & & $\mathrm{AC}$ & PAC & Q-Stat & Prob... \\
\hline 1 & 10 & 1 & 0.033 & 0.033 & 0.0937 & \\
\hline 1 & 1 1 & 2 & 0.037 & 0.036 & 0.2158 & 0.642 \\
\hline ו口 & ו 口 & 3 & 0.150 & 0.148 & 2.2278 & 0.328 \\
\hline ו & ו & 4 & 0.054 & 0.045 & 2.4886 & 0.477 \\
\hline । & 口 & 5 & $-0.18 \ldots$ & $-0.20 \ldots$ & 5.5878 & 0.232 \\
\hline 11 & 14 & 6 & $-0.03 \ldots$ & $-0.05 \ldots$ & 5.7317 & 0.333 \\
\hline 1 & 다 । & 7 & $-0.10 \ldots$ & $-0.10 \ldots$ & 6.7128 & 0.348 \\
\hline 1 & । प्र & 8 & $-0.12 \ldots$ & $-0.06 \ldots$ & 8.2343 & 0.312 \\
\hline 1 & 1 & 9. & $-0.14 \ldots$ & $-0.10 \ldots$ & 10.214 & 0.250 \\
\hline ין & ا & $1 \ldots$ & 0.134 & 0.160 & 11.973 & 0.215 \\
\hline$\square$, & $\square$, & $1 \ldots$ & $-0.27 \ldots$ & $-0.27 \ldots$ & 19.406 & 0.035 \\
\hline 11 & 1 . & $\mid 1 \ldots$ & 0.019 & 0.044 & 19.441 & 0.054 \\
\hline
\end{tabular}

As it can be seen from Figure 1, the autocorrelation coefficients in the residual component have low values and they are not statistically significant. The conducted tests warranted the assumption that the constructed econometric model was correct, and the results were credible.

\section{Romania}

The econometric model for Romania is assessed by the least squares method and the results are as follows:

Table 2. Results from the econometric model for Romania

\begin{tabular}{|c|c|c|c|c|}
\hline \multicolumn{5}{|c|}{$\begin{array}{l}\text { Dependent Variable: ROMANIA_BONDS } \\
\text { Method: ARMA Generalized Least Squares (Gauss-Newton) } \\
\text { Sample: 2010M01 2016M12 } \\
\text { Included observations: } 84 \\
\text { Convergence achieved after } 11 \text { iterations } \\
\text { Coefficient covariance computed using outer product of gradients } \\
\text { d.f. adjustment for standard errors \& covariance }\end{array}$} \\
\hline Variable & Coefficient & Std. Error & t-Statistic & Prob. \\
\hline C & 8.398432 & 0.422345 & 19.88526 & 0.0000 \\
\hline EU_EONIA & -0.119665 & 0.383730 & -0.311847 & 0.7560 \\
\hline$T$ & -0.067108 & 0.008111 & -8.274133 & 0.0000 \\
\hline $\operatorname{AR}(1)$ & 1.181392 & 0.110215 & 10.71902 & 0.0000 \\
\hline AR(2) & -0.344058 & 0.110606 & -3.110651 & 0.0026 \\
\hline
\end{tabular}




\begin{tabular}{|llll|}
\hline \hline R-squared & 0.975566 & Mean dependent var & 5.430595 \\
Adjusted R-squared & 0.974328 & S.D. dependent var & 1.651617 \\
S.E. of regression & 0.264628 & Akaike info criterion & 0.257330 \\
Sum squared resid & 5.532231 & Schwarz criterion & 0.402022 \\
Log likelihood & -5.807861 & Hannan-Quinn criter. & 0.315495 \\
F-statistic & 788.5335 & Durbin-Watson stat & 2.198622 \\
Continues & & & \\
Prob(F-statistic) & 0.000000 & & \\
\hline \hline
\end{tabular}

The following conclusions can be drawn from the results:

First of all, it can be assumed that the developed econometric model is adequate. This is confirmed by the F-test-Prob (F-statistic) $<\alpha$, where $\alpha=0,05$. In addition, the model has a very high explanatory power $-\mathrm{R}^{2}=0,97$. This means that $97 \%$ of the interest rate changes of the long-term securities issued by the Romanian government can be explained by changes in the two factors - EONIA and the time. In addition, time has a statistically significant impact since the level of significance (prob.) is quite lower than the assumed risk of error $\alpha$, but the EONIA has no impact. The next step is to test for serial autocorrelation, i.e. whether autocorrelation exists in the residual component $\varepsilon_{t}$. This was done by the calculation of the autocorrelation coefficients and by the construction of the autocorrelogramof $\varepsilon_{t}$. The results are presented in Figure 2.

Figure 2. Autocorrelogram of the residual component $\varepsilon_{t}$

Sample: 2010M01 2016M12

Included observations: 84

Q-statistic probabilities adjusted for 2 ARMA terms

\begin{tabular}{|c|c|c|c|c|c|}
\hline Autocorrelation & Partial Correlation & $\mathrm{AC}$ & PAC & Q-Stat & Prob... \\
\hline 미 । & 미 । & $1-0.09 \ldots$ & $-0.09 \ldots$ & 0.8475 & \\
\hline 1 & 11 & $2-0.00 \ldots$ & $-0.01 \ldots$ & 0.8527 & \\
\hline 1 & 1 & 30.039 & 0.037 & 0.9885 & 0.320 \\
\hline ，口。 & ı & $4 \quad 0.155$ & 0.164 & 3.1486 & 0.207 \\
\hline 면 & 담 & $5-0.15 \ldots$ & $-0.13 \ldots$ & 5.4488 & 0.142 \\
\hline ו & 1 & $\begin{array}{ll}6 & 0.083\end{array}$ & 0.059 & 6.0805 & 0.193 \\
\hline 101 & 1 & $7 \quad 0.055$ & 0.053 & 6.3603 & 0.273 \\
\hline $1[1$ & 1 & 80.022 & 0.023 & 6.4067 & 0.379 \\
\hline 1 & 1 प 1 & $9-0.11 \ldots$ & $-0.08 \ldots$ & 7.7370 & 0.356 \\
\hline י 口 & , 口 & | $1 \ldots .151$ & 0.096 & 9.9563 & 0.26 \\
\hline 10 & 101 & $1 \ldots-0.07 \ldots$ & $-0.06 \ldots$ & 10.550 & 0.308 \\
\hline 101 & 1 1 1 & $\mid 1 \ldots-0.06 \ldots$ & $-0.06 \ldots$ & 10.911 & 0.364 \\
\hline
\end{tabular}

As it can be seen from Figure 2, the autocorrelation coefficients have small values and are not statistically significant. Since one of the parameters in front of the factors 
can be considered statistically significant, it can be interpreted. From the obtained results, the following two conclusions can be made:

1. The levels of EONIA did not have a statically significant impact on the yield on the Romanian long-term government bonds.

2. At fixed rates of EONIA each month the interest rate on the long-term securities of the Romanian government is expected to decrease by 0,067108 p.p.

\section{Denmark}

The econometric model for Denmark is assessed by the least squares method and the results are as follows:

Table 3. Results from the econometric model for Denmark

\begin{tabular}{|c|c|c|c|c|}
\hline \multicolumn{5}{|c|}{$\begin{array}{l}\text { Dependent Variable: DENMARK_BONDS } \\
\text { Method: ARMA Generalized Least Squares (Gauss-Newton) } \\
\text { Sample: 2010M01 2016M12 } \\
\text { Included observations: } 84 \\
\text { Convergence achieved after } 8 \text { iterations } \\
\text { Coefficient covariance computed using outer product of gradients } \\
\text { d.f. adjustment for standard errors \& covariance }\end{array}$} \\
\hline Variable & Coefficient & Std. Error & t-Statistic & Prob. \\
\hline $\begin{array}{l}\text { C } \\
\text { EU_EONIA } \\
T \\
\operatorname{AR}(1) \\
\operatorname{AR}(2)\end{array}$ & $\begin{array}{l}3.036596 \\
0.194972 \\
-0.033975 \\
1.211032 \\
-0.354148\end{array}$ & $\begin{array}{l}0.302750 \\
0.262591 \\
0.005770 \\
0.106993 \\
0.106633\end{array}$ & $\begin{array}{l}10.03006 \\
0.742494 \\
-5.888257 \\
11.31883 \\
-3.321179\end{array}$ & $\begin{array}{l}0.0000 \\
0.4600 \\
0.0000 \\
0.0000 \\
0.0014\end{array}$ \\
\hline $\begin{array}{l}\text { R-squared } \\
\text { Adjusted R-squared } \\
\text { S.E. of regression } \\
\text { Sum squared resid } \\
\text { Log likelihood } \\
\text { F-statistic } \\
\text { Prob(F-statistic) }\end{array}$ & $\begin{array}{l}0.968869 \\
0.967293 \\
0.174385 \\
2.402399 \\
29.15361 \\
614.6675 \\
0.000000\end{array}$ & \multicolumn{2}{|c|}{$\begin{array}{l}\text { Mean dependent var } \\
\text { S.D. dependent var } \\
\text { Akaike info criterion } \\
\text { Schwarz criterion } \\
\text { Hannan-Quinn criter. } \\
\text { Durbin-Watson stat }\end{array}$} & $\begin{array}{l}1.592143 \\
0.964245 \\
-0.575086 \\
-0.430394 \\
-0.516921 \\
1.985624\end{array}$ \\
\hline
\end{tabular}

The following conclusions can be drawn from the results:

The developed econometric model is adequate, confirmed by the F-test-Prob (Fstatistic) $<\alpha$, where $\alpha=0,05$. The model has a very high explanatory power $-\mathrm{R}^{2}=$ 0,97 . This means that $97 \%$ of the interest rate changes of the long-term securities issued by the Danish government can be explained by changes in the two factors EONIA and the time. In addition, time has a statistically significant impact since the level of significance (prob.) is quite lower than the assumed risk of error $\alpha$, but the EONIA has no impact. The next step is to check for serial autocorrelation, i.e. whether autocorrelation exists in the residual component $\varepsilon_{t}$. This was done by the 
calculation of the autocorrelation coefficients and by the construction of the autocorrelogramof $\varepsilon_{t}$. The results are presented in Figure 3.

Figure 3. Autocorrelogram of the residual component $\varepsilon_{t}$

Sample: $2010 \mathrm{M} 012016 \mathrm{M} 12$

Included observations: 84

Q-statistic probabilities adjusted for 2 ARMA terms

\begin{tabular}{|c|c|c|c|c|c|}
\hline Autocorrelation & Partial Correlation & $\mathrm{AC}$ & PAC & Q-Stat & Prob... \\
\hline 1 & I & $1-0.00 \ldots$ & $-0.00 \ldots$ & 0.0012 & \\
\hline 1 & I & $2-0.10 \ldots$ & $-0.10 \ldots$ & 0.9566 & \\
\hline ו & , 口 & 30.111 & 0.111 & 2.0535 & 0.152 \\
\hline 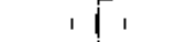 & 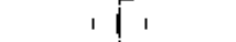 & $4-0.01 \ldots$ & $-0.02 \ldots$ & 2.0634 & 0.356 \\
\hline 1 & 1 & $\begin{array}{ll}5 & 0.027\end{array}$ & 0.051 & 2.1286 & 0.546 \\
\hline 1 & 1 & $6-0.05 \ldots$ & $-0.07 \ldots$ & 2.4259 & 0.658 \\
\hline 101 & ו & $\begin{array}{ll}7 & 0.038\end{array}$ & 0.054 & 2.5637 & 0.767 \\
\hline $1 \mid 1$ & 1 & $8-0.00 \ldots$ & $-0.03 \ldots$ & 2.5689 & 0.861 \\
\hline 口 । & 인 & $9-0.22 \ldots$ & $-0.20 \ldots$ & 7.4906 & 0.380 \\
\hline 1 & 1 & |1... 0.007 & $-0.00 \ldots$ & 7.4949 & 0.484 \\
\hline ו י ו & ו & 1... 0.110 & 0.081 & 8.6996 & 0.465 \\
\hline 101 & ו ים & |1... 0.061 & 0.109 & 9.0677 & 0.526 \\
\hline
\end{tabular}

As it can be seen from Figure 3, the autocorrelation coefficients have small values and are not statistically significant. Since one of the parameters in front of the factors can be considered statistically significant, it can be interpreted. From the obtained results, the following two conclusions can be made:

1. The levels of EONIA did not have a statically significant impact on the yield on the Danish long-term government bonds.

2. At fixed rates of EONIA each month the interest rate on the long-term securities of the Danish government is expected to decrease by 0,033975 p.p.

\section{Poland}

The econometric model for Poland is assessed by the least squares method and the results are as follows:

Table 4. Results from the econometric model for Poland

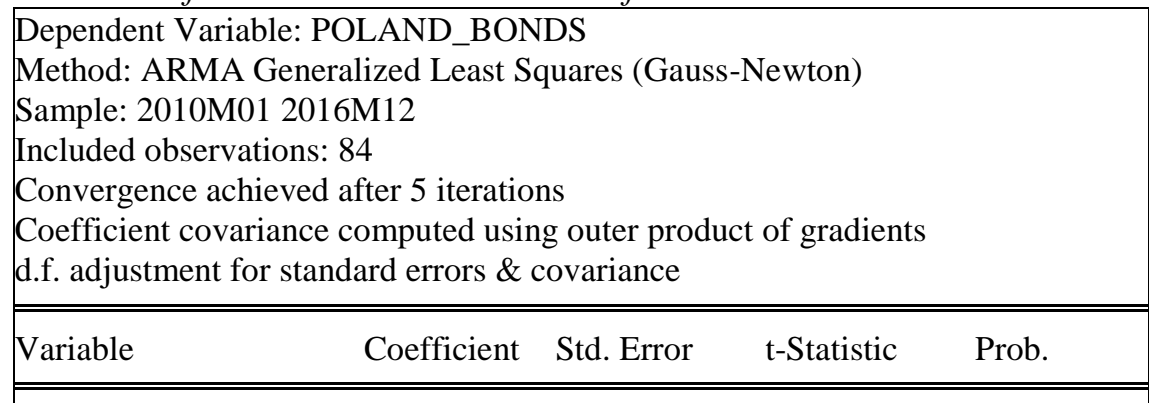




\begin{tabular}{|lllll|} 
C & 6.123569 & 0.447961 & 13.66988 & 0.0000 \\
EU_EONIA & 0.049052 & 0.279548 & 0.175470 & 0.8612 \\
T & -0.041581 & 0.008978 & -4.631185 & 0.0000 \\
AR(1) & 1.305130 & 0.104794 & 12.45423 & 0.0000 \\
AR(2) & -0.393096 & 0.107721 & -3.649220 & 0.0005 \\
\hline \hline R-squared & & & \\
Continues & 0.979075 & Mean dependent var & 4.289167 \\
& 0.978016 & S.D. dependent var & 1.282626 \\
Adjusted R-squared & 0.190176 & Akaike info criterion & -0.395042 \\
S.E. of regression & 2.857190 & Schwarz criterion & -0.250350 \\
Sum squared resid & 21.59175 & Hannan-Quinn criter. & -0.336877 \\
Log likelihood & 924.1060 & Durbin-Watson stat & 1.962321 \\
F-statistic & 0.000000 & & \\
Prob(F-statistic) & & & \\
\hline \hline
\end{tabular}

The following conclusions can be drawn from the results:

The developed econometric model is adequate, confirmed by the F-test-Prob (Fstatistic) $<\alpha$, where $\alpha=0,05$. The model has a very high explanatory power $-\mathrm{R}^{2}=$ 0,979 , meaning that $97,9 \%$ of the interest rate changes of the long-term securities issued by the Polish government can be explained by changes in the two factors EONIA and the time. In addition, time has a statistically significant impact since the level of significance (prob.) is quite lower than the assumed risk of error $\alpha$, but the EONIA has no impact.

The next step is to test for serial autocorrelation, i.e. whether autocorrelation exists in the residual component $\varepsilon_{t}$. This was done by the calculation of the autocorrelation coefficients and by the construction of the autocorrelogramof $\varepsilon_{t}$. The results are presented in Figure 4.

As it can be seen from Figure 4, the autocorrelation coefficients have small values and are not statistically significant. Since one of the parameters in front of the factors can be considered statistically significant, it can be interpreted. From the obtained results, the following two conclusions can be made:

1. The levels of EONIA did not have a statically significant impact on the yield on the Polish long-term government bonds.

2. At fixed rates of EONIA each month the interest rate on the long-term securities of the Polish government is expected to decrease by 0,041581 p.p. 
Figure 4. Autocorrelogram of the residual component $\mathcal{E}_{t}$

Sample: 2010M01 2016M12

Included observations: 84

Q-statistic probabilities adjusted for 2 ARMA terms

\begin{tabular}{|c|c|c|c|c|c|c|}
\hline Autocorrelation & Partial Correlation & & $A C$ & PAC & Q-Stat & Prob... \\
\hline $1 \mid 1$ & $1 \mid 1$ & 1 & 0.018 & 0.018 & 0.0285 & \\
\hline 1 d 1 & 1 㝴 1 & & $-0.05 \ldots$ & $-0.05 \ldots$ & 0.2894 & \\
\hline 1 & 1 & 3 & 0.023 & 0.025 & 0.3373 & 0.561 \\
\hline 1 1 & 1 । & & $-0.07 \ldots$ & $-0.07 \ldots$ & 0.7770 & 0.678 \\
\hline ו & ı 口 & 5 & 0.149 & 0.156 & 2.8139 & 0.421 \\
\hline ו & ו & 6 & 0.147 & 0.134 & 4.8037 & 0.308 \\
\hline 1 1 & 11 & 7 & $-0.05 \ldots$ & $-0.03 \ldots$ & 5.0461 & 0.410 \\
\hline 1 & । 마 । & 8 & $-0.14 \ldots$ & $-0.15 \ldots$ & 7.1205 & 0.310 \\
\hline 1 & 101 & 9 & 0.038 & 0.055 & 7.2584 & 0.402 \\
\hline 1 & 11 & $1 \ldots$ & 0.000 & $-0.01 \ldots$ & 7.2584 & 0.509 \\
\hline 11 & 1 1 & $1 \ldots$ & $-0.03 \ldots$ & $-0.07 \ldots$ & 7.4033 & 0.595 \\
\hline 111 & 1 1 & $1 \ldots$ & $-0.01 \ldots$ & $-0.05 \ldots$ & 7.4313 & 0.684 \\
\hline
\end{tabular}

\section{Hungary}

The econometric model for Hungary is assessed by the least squares method and the results are as follows:

Table 5. Results from the econometric model for Hungary

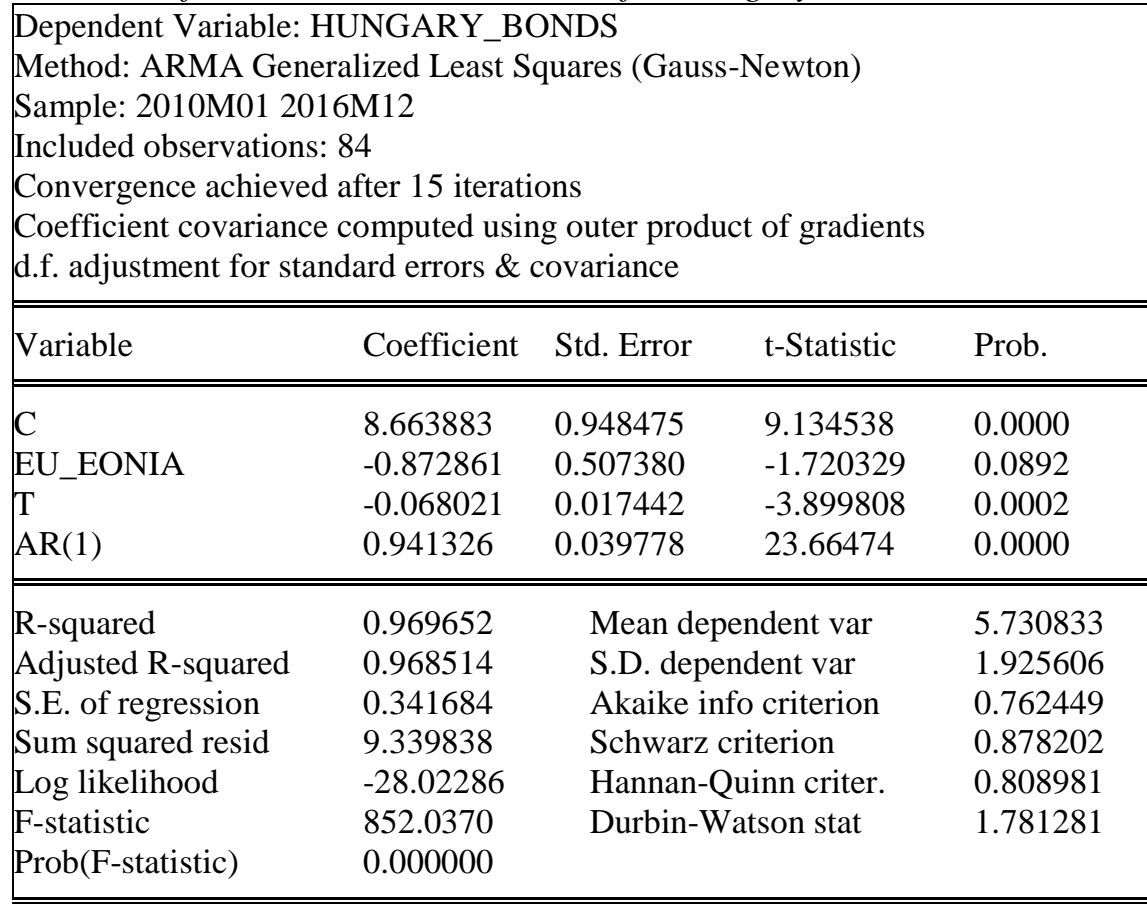

The following conclusions can be drawn from the results: 
The developed econometric model is adequate, confirmed by the F-test-Prob (Fstatistic) $<\alpha$, where $\alpha=0,05$. The model has a very high explanatory power $-\mathrm{R}^{2}=$ 0,97 , meaning that $97 \%$ of the interest rate changes of the long-term securities issued by the Hungarian government can be explained by changes in the two factors EONIA and the time. In addition, time has a statistically significant impact since the level of significance (prob.) is quite lower than the assumed risk of error $\alpha$, but the EONIA has no impact.

The next step is to check for serial autocorrelation, i.e. whether autocorrelation exists in the residual component $\varepsilon_{t}$. This was done by the calculation of the autocorrelation coefficients and by the construction of the autocorrelogramof $\varepsilon_{t}$. The results are presented in Figure 5.

Figure 5. Autocorrelogram of the residual component $\varepsilon_{t}$

Sample: 2010M012016M12

Included observations: 84

Q-statistic probabilities adjusted for 1 ARMA term

\begin{tabular}{|c|c|c|c|c|c|c|}
\hline Autocorrelation & Partial Correlation & & $\mathrm{AC}$ & PAC & Q-Stat & Prob... \\
\hline ， 口 & י 口 & & 10.105 & 0.105 & 0.9571 & \\
\hline 1 1 & 1 1 & & $2-0.07 \ldots$ & $-0.08 \ldots$ & 1.4540 & 0.228 \\
\hline 1 & 101 & & 30.035 & 0.053 & 1.5609 & 0.458 \\
\hline 1 प1 & 1 1 & & $4-0.10 \ldots$ & $-0.12 \ldots$ & 2.6147 & 0.455 \\
\hline । 口 & $1 \square$ & & $5 \quad 0.227$ & 0.272 & 7.3082 & 0.120 \\
\hline ı 口 & ו & & $\begin{array}{ll}6 & 0.187\end{array}$ & 0.104 & 10.540 & 0.061 \\
\hline 1 | & 11 & & $7-0.03 \ldots$ & $-0.01 \ldots$ & 10.673 & 0.099 \\
\hline 1 . & 1 प्रे & & $-0.08 \ldots$ & $-0.10 \ldots$ & 11.371 & 0.123 \\
\hline 11 & 1 & & $9-0.03 \ldots$ & 0.028 & 11.498 & 0.175 \\
\hline 101 & । & 1. & $-0.08 \ldots$ & $-0.13 \ldots$ & 12.250 & 0.200 \\
\hline 1 . & । & 1. & $-0.10 \ldots$ & $-0.17 \ldots$ & 13.415 & 0.201 \\
\hline ו & 101 & 1. & 0.057 & 0.048 & 13.742 & 0.248 \\
\hline
\end{tabular}

As it can be seen from Figure 5, the autocorrelation coefficients have small values and are not statistically significant. Since one of the parameters in front of the factors can be considered statistically significant, it can be interpreted. From the obtained results, the following two conclusions can be made:

1. The levels of EONIA did not have a statically significant impact on the yield on the Hungarian long-term government bonds.

2. At fixed rates of EONIA each month the interest rate on the long-term securities of the Hungariangovernment is expected to decrease by 0,068021 p.p.

\section{Croatia}

The econometric model for Croatia is assessed by the least squares method and the results are as follows: 
Table 6. Results from the econometric model for Croatia

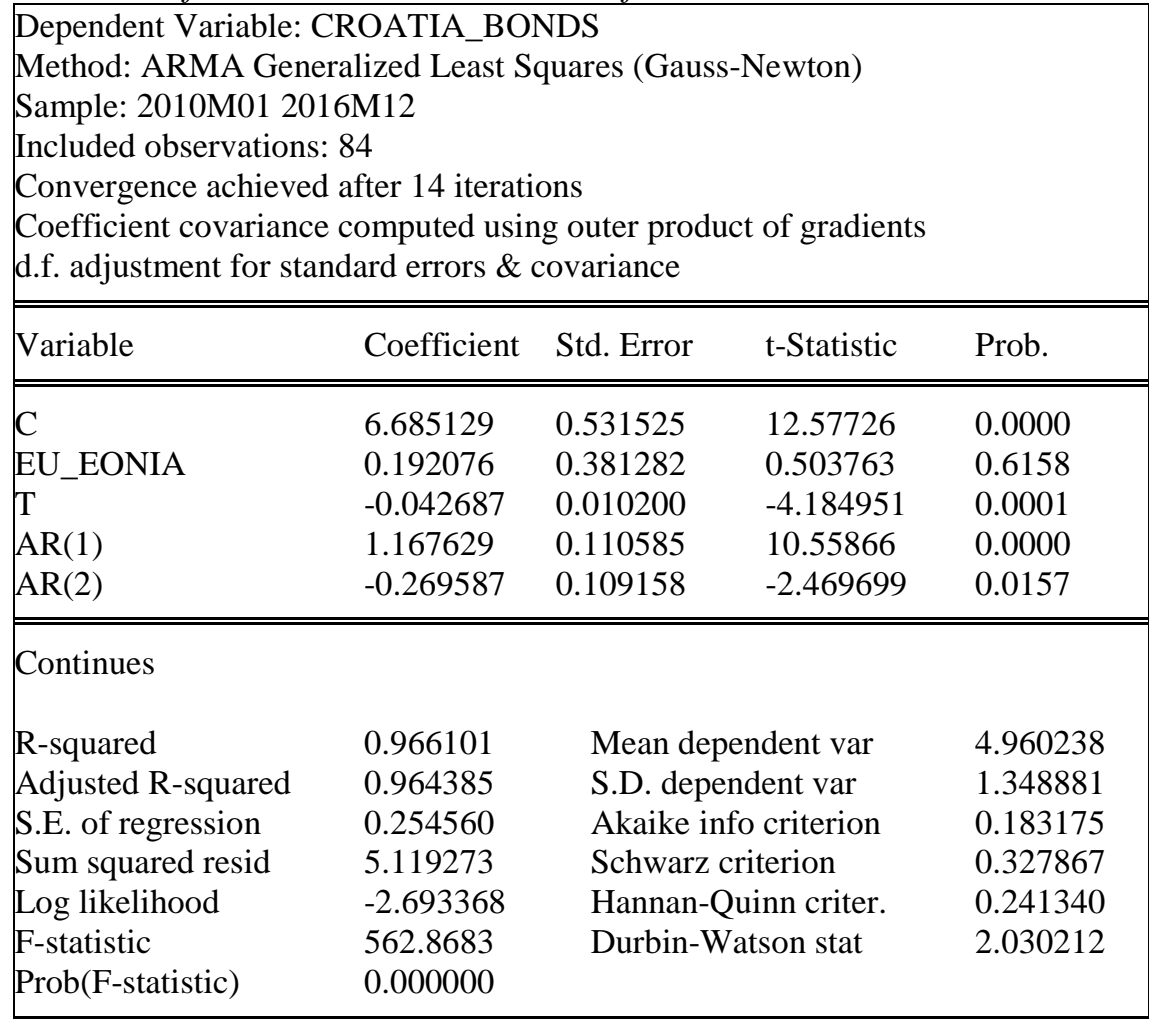

The following conclusions can be drawn from the results:

The developed econometric model is adequate, confirmed by the F-test-Prob (Fstatistic) $<\alpha$, where $\alpha=0,05$. The model has a very high explanatory power $-\mathrm{R}^{2}=$ 0,97 , meaning that $97 \%$ of the interest rate changes of the long-term securities issued by the Croatian government can be explained by changes in the two factors EONIA and the time. In addition, time has a statistically significant impact since the level of significance (prob.) is quite lower than the assumed risk of error $\alpha$, but the EONIA has no impact. The next step is to check for serial autocorrelation, i.e. whether autocorrelation exists in the residual component $\varepsilon_{t}$. This was done by the calculation of the autocorrelation coefficients and by the construction of the autocorrelogramof $\varepsilon_{t}$. The results are presented in Figure 6.

As it can be seen from Figure 6, the autocorrelation coefficients have small values and are not statistically significant. Since one of the parameters in front of the factors can be considered statistically significant, it can be interpreted. From the obtained results, the following two conclusions can be made: 
1. The levels of EONIA did not have a statically significant impact on the yield on the Croatian long-term government bonds.

2. At fixed rates of EONIA each month the interest rate on the long-term securities of the Croatian government is expected to decrease by 0,042687 p.p.

Figure 6. Autocorrelogram of the residual component $\varepsilon_{t}$

Sample: 2010M012016M12

Included observations: 84

Q-statistic probabilities adjusted for 2 ARMA terms

\begin{tabular}{|c|c|c|c|c|c|}
\hline Autocorrelation & Partial Correlation & $\mathrm{AC}$ & PAC & Q-Stat & Prob... \\
\hline $1 \| 1$ & 101 & $1-0.02 \ldots$ & $-0.02 \ldots$ & 0.0537 & \\
\hline 11 & 11 & $2-0.03 \ldots$ & $-0.04 \ldots$ & 0.1880 & \\
\hline ı 口ı & ı 口ı & $\begin{array}{ll}3 & 0.159\end{array}$ & 0.157 & 2.4351 & 0.119 \\
\hline $1 \mid 1$ & & $4-0.00 \ldots$ & $-0.00 \ldots$ & 2.4386 & 0.295 \\
\hline 11 & 1 & $\begin{array}{ll}5 & 0.031\end{array}$ & 0.044 & 2.5268 & 0.470 \\
\hline 11 & 1 & $6-0.01 \ldots$ & $-0.03 \ldots$ & 2.5435 & 0.637 \\
\hline 1 & 11 & 70.006 & 0.009 & 2.5464 & 0.769 \\
\hline 11 & 11 & $8-0.00 \ldots$ & $-0.02 \ldots$ & 2.5520 & 0.863 \\
\hline 1이 & 뎐 & $9-0.12 \ldots$ & $-0.11 \ldots$ & 3.9663 & 0.784 \\
\hline ㄷ․ & 마. & $1 \ldots-0.19 \ldots$ & $-0.21 \ldots$ & 7.8054 & 0.453 \\
\hline 181 & 101 & | $1 \ldots .0 .073$ & 0.062 & 8.3360 & 0.501 \\
\hline 1 다 & 1 प 1 & $1 \ldots-0.09 \ldots$ & $-0.07 \ldots$ & 9.1668 & 0.516 \\
\hline
\end{tabular}

\section{Czech Republic}

The econometric model for the Czech Republic is assessed by the least squares method and the results are as follows:

Table 7. Results from the econometric model for the Czech Republic

Dependent Variable: CZECHREPUBLIC_BONDS

Method: ARMA Generalized Least Squares (Gauss-Newton)

Sample: 2010M01 2016M12

Included observations: 84

Convergence achieved after 7 iterations

Coefficient covariance computed using outer product of gradients

d.f. adjustment for standard errors \& covariance

\begin{tabular}{|lllll|}
\hline \hline Variable & Coefficient & Std. Error & t-Statistic & Prob. \\
\hline \hline C & 4.237365 & 0.246216 & 17.20997 & 0.0000 \\
EU_EONIA & 0.194921 & 0.251564 & 0.774834 & 0.4408 \\
T & -0.049697 & 0.004656 & -10.67384 & 0.0000 \\
AR(1) & 1.207703 & 0.102476 & 11.78519 & 0.0000 \\
AR(2) & -0.424593 & 0.104513 & -4.062574 & 0.0001 \\
\hline \hline R-squared & 0.983109 & Mean dependent var & 2.151905 \\
Adjusted R-squared & 0.982253 & S.D. dependent var & 1.348561 \\
S.E. of regression & 0.179651 & Akaike info criterion & -0.518093 \\
Sum squared resid & 2.549680 & Schwarz criterion & -0.373401
\end{tabular}




\begin{tabular}{|llll|} 
Log likelihood & 26.75989 & Hannan-Quinn criter. & -0.459928 \\
F-statistic & 1149.483 & Durbin-Watson stat & 1.779348 \\
Prob(F-statistic) & 0.000000 & & \\
\hline
\end{tabular}

The following conclusions can be drawn from the results:

The developed econometric model is adequate, confirmed by the F-test-Prob (Fstatistic) $<\alpha$, where $\alpha=0,05$. The model has a very high explanatory power $-\mathrm{R}^{2}=$ 0,98 , meaning that $98 \%$ of the interest rate changes of the long-term securities issued by the Czech government can be explained by changes in the two factors -EONIA and the time. In addition, time has a statistically significant impact since the level of significance (prob.) is quite lower than the assumed risk of error $\alpha$, but the EONIA has no impact. The next step is to check for serial autocorrelation, i.e. whether autocorrelation exists in the residual component $\varepsilon_{t}$. This was done by the calculation of the autocorrelation coefficients and by the construction of the autocorrelogramof $\varepsilon_{t}$. The results are presented in Figure 7.

Figure 7. Autocorrelogram of the residual component $\varepsilon_{t}$

Sample: 2010M01 2016M12

Included observations: 84

Q-statistic probabilities adjusted for 2 ARMA terms

\begin{tabular}{|c|c|c|c|c|c|}
\hline Autocorrelation & Partial Correlation & $A C$ & PAC & Q-Stat & Prob... \\
\hline , 只 & ， 中 & 10.110 & 0.110 & 1.0523 & \\
\hline ㅁ. & ㅁ. & $2-0.22 \ldots$ & $-0.24 \ldots$ & 5.5241 & \\
\hline 11 & 101 & $3-0.01 \ldots$ & 0.043 & 5.5512 & 0.018 \\
\hline 口 & ו & $\begin{array}{ll}4 & 0.197\end{array}$ & 0.150 & 9.0651 & 0.011 \\
\hline 101 & 11 & $\begin{array}{ll}5 & 0.061\end{array}$ & 0.020 & 9.4095 & 0.024 \\
\hline 11 & 1 & $\begin{array}{ll}6 & 0.017\end{array}$ & 0.090 & 9.4374 & 0.051 \\
\hline I & $1[1$ & $\begin{array}{ll}7 & 0.002\end{array}$ & 0.004 & 9.4378 & 0.093 \\
\hline 吅, & ㄴ, & $8-0.17 \ldots$ & $-0.20 \ldots$ & 12.380 & 0.054 \\
\hline 101 & 11 & $9-0.06 \ldots$ & $-0.03 \ldots$ & 12.789 & 0.077 \\
\hline 111 & 101 & 1... 0.030 & $-0.06 \ldots$ & 12.877 & 0.116 \\
\hline 111 & 11 & 1... 0.012 & $-0.01 \ldots$ & 12.890 & 0.168 \\
\hline 다. & , प1 & $1 \ldots-0.15 \ldots$ & $-0.09 \ldots$ & 15.272 & 0.122 \\
\hline
\end{tabular}

As it can be seen from Figure 7, the autocorrelation coefficients have small values and are not statistically significant. Since one of the parameters in front of the factors can be considered statistically significant, it can be interpreted. From the obtained results, the following two conclusions can be made:

1. The levels of EONIA did not have a statically significant impact on the yield on the Czech long-term government bonds.

2. At fixed rates of EONIA each month the interest rate on the long-term securities of the Czech government is expected to decrease by 0,049697 p.p. 


\section{Sweden}

The econometric model for Sweden is assessed by the least squares method and the results are as follows:

Table 8. Results from the econometric model for Sweden

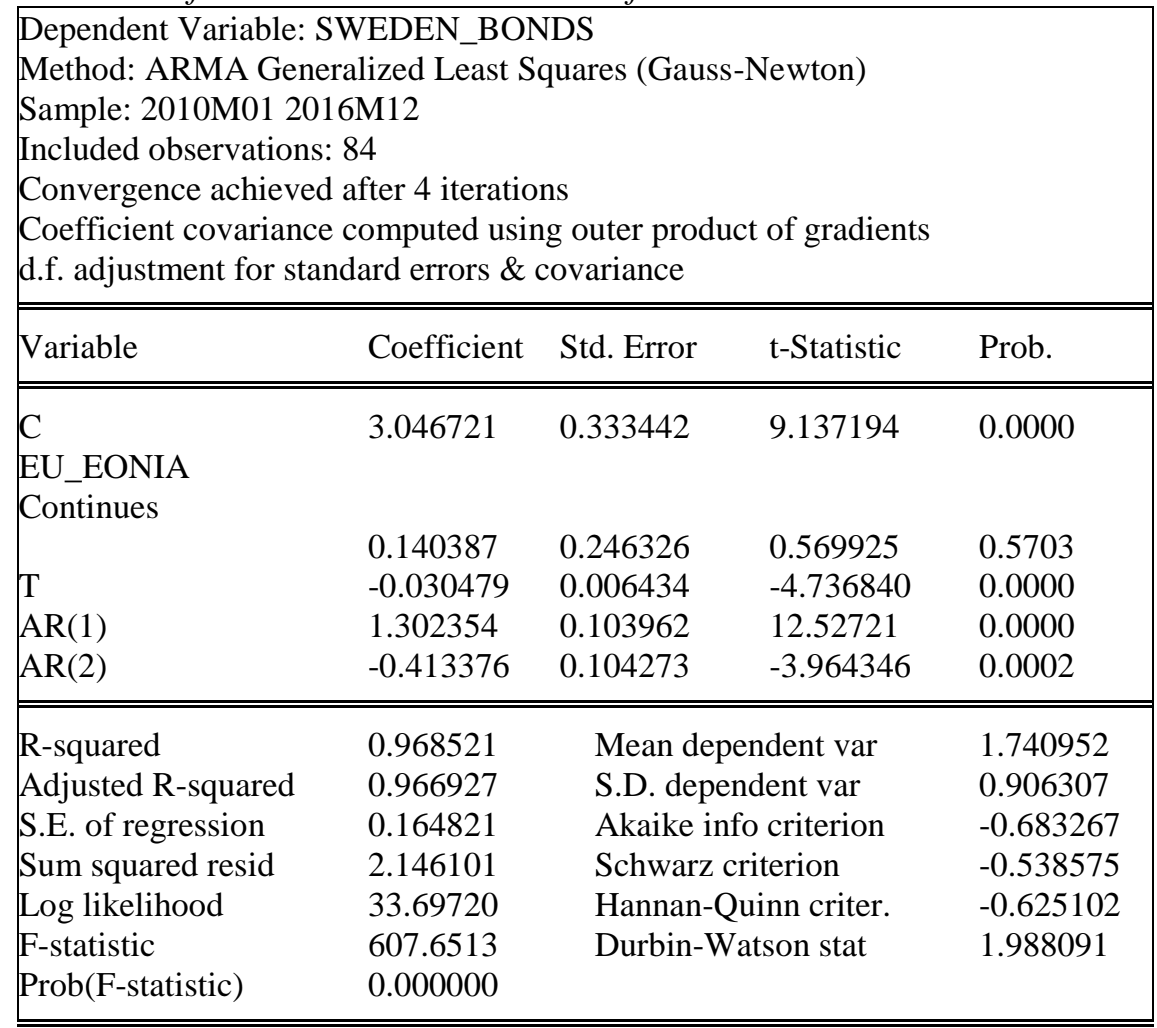

The following conclusions can be drawn from the results:

The developed econometric model is adequate, confirmed by the F-test-Prob (Fstatistic) $<\alpha$, where $\alpha=0,05$. The model has a very high explanatory power $-\mathrm{R}^{2}=$ 0,97 , meaning that $97 \%$ of the interest rate changes of the long-term securities issued by the Swedish government can be explained by changes in the two factors EONIA and the time. In addition, time has a statistically significant impact since the level of significance (prob.) is quite lower than the assumed risk of error $\alpha$, but the EONIA has no impact. The next step is to check for serial autocorrelation, i.e. whether autocorrelation exists in the residual component $\varepsilon_{t}$. This was done by the calculation of the autocorrelation coefficients and by the construction of the autocorrelogramof $\varepsilon_{t}$. The results are presented in Figure 8. 
Figure 8. Autocorrelogram of the residual component $\mathcal{E}_{t}$

Sample: 2010M012016M12

Included observations: 84

Q-statistic probabilities adjusted for 2 ARMA terms

\begin{tabular}{|c|c|c|c|c|c|}
\hline Autocorrelation & Partial Correlation & $\mathrm{AC}$ & PAC & Q-Stat & Prob... \\
\hline $1 \mid 1$ & $1 \mid 1$ & $1-0.00 \ldots$ & $-0.00 \ldots$ & 2.E-05 & \\
\hline 1 & 1 & $2-0.11 \ldots$ & $-0.11 \ldots$ & 1.0835 & \\
\hline ， 口 & ， 口 & $\begin{array}{ll}3 & 0.176\end{array}$ & 0.178 & 3.8357 & 0.050 \\
\hline 11 & \begin{tabular}{l|l}
1 & 1
\end{tabular} & $4 \quad 0.010$ & $-0.00 \ldots$ & 3.8454 & 0.146 \\
\hline 10 & 11 & $5-0.06 \ldots$ & -0.02 . & 4.1868 & 0.242 \\
\hline 101 & 1 & $\begin{array}{ll}6 & 0.061\end{array}$ & 0.033 & 4.5317 & 0.339 \\
\hline 1 1 1 & । प्र 1 & $7-0.06 \ldots$ & $-0.08 \ldots$ & 4.9522 & 0.422 \\
\hline 11, & 111 & $8-0.01 \ldots$ & 0.014 & 4.9737 & 0.547 \\
\hline 1 & , & $9-0.11 \ldots$ & $-0.15 \ldots$ & 6.2515 & 0.511 \\
\hline \begin{tabular}{l|l}
1 & 1
\end{tabular} & 1 & $1 \ldots-0.00 \ldots$ & 0.030 & 6.2517 & 0.619 \\
\hline 10 & 1 & 1... 0.041 & 0.017 & 6.4178 & 0.697 \\
\hline ים & ， 口 & 1... 0.145 & 0.197 & 8.5266 & 0.578 \\
\hline
\end{tabular}

As it can be seen from Figure 8, the autocorrelation coefficients have small values and are not statistically significant. Since one of the parameters in front of the factors can be considered statistically significant, it can be interpreted. From the obtained results, the following two conclusions can be made:

1. The levels of EONIA did not have a statically significant impact on the yield on the Swedish long-term government bonds.

2. At fixed rates of EONIA each month the interest rate on the long-term securities of the Swedish government is expected to decrease by 0,030479 p.p.

\section{United Kingdom}

The model for the UK is assessed by the least squares method and the results are as follows:

Table 9. Results from the econometric model for United Kingdom

\begin{tabular}{|c|c|c|c|c|}
\hline \multicolumn{5}{|c|}{$\begin{array}{l}\text { Dependent Variable: UNITEDKINGDOM_BONDS } \\
\text { Method: ARMA Generalized Least Squares (Gauss-Newton) } \\
\text { Sample: 2010M01 2016M12 } \\
\text { Included observations: } 84 \\
\text { Convergence achieved after } 9 \text { iterations } \\
\text { Coefficient covariance computed using outer product of gradients } \\
\text { d.f. adjustment for standard errors \& covariance }\end{array}$} \\
\hline Variable & Coefficient & Std. Error & t-Statistic & Prob. \\
\hline C & 3.247986 & 0.376381 & 8.629525 & 0.0000 \\
\hline EU_EONIA & 0.157333 & 0.254234 & 0.618849 & 0.5378 \\
\hline $\mathrm{T}$ & -0.025173 & 0.007281 & -3.457350 & 0.0009 \\
\hline
\end{tabular}




\begin{tabular}{|lllll|} 
AR(1) & 1.354713 & 0.102349 & 13.23622 & 0.0000 \\
$\operatorname{AR}(2)$ & -0.457236 & 0.101043 & -4.525151 & 0.0000 \\
\hline \hline R-squared & 0.954403 & Mean dependent var & 2.159881 \\
Adjusted R-squared & 0.952095 & S.D. dependent var & 0.795356 \\
S.E. of regression & 0.174082 & Akaike info criterion & -0.571544 \\
Sum squared resid & 2.394062 & Schwarz criterion & -0.426853 \\
Log likelihood & 29.00485 & Hannan-Quinn criter. & -0.513379 \\
F-statistic & 413.3949 & Durbin-Watson stat & 1.997748 \\
Prob(F-statistic) & 0.000000 & & \\
\hline \hline
\end{tabular}

The following conclusions can be drawn from the results:

The developed econometric model is adequate, confirmed by the F-test-Prob (Fstatistic) $<\alpha$, where $\alpha=0,05$. The model has a very high explanatory power $-\mathrm{R}^{2}=$ 0,95 , meaning that $95 \%$ of the interest rate changes of the long-term securities issued by the UK government can be explained by changes in the two factors - EONIA and the time. In addition, time has a statistically significant impact since the level of significance (prob.) is quite lower than the assumed risk of error $\alpha$, but the EONIA has no impact. The next step is to check for serial autocorrelation, i.e. whether autocorrelation exists in the residual component $\varepsilon_{t}$. This was done by the calculation of the autocorrelation coefficients and by the construction of the autocorrelogramof $\varepsilon_{t}$. The results are presented in Figure 9.

Figure 9. Autocorrelogram of the residual component $\varepsilon_{t}$

Sample: 2010M01 2016M12

Included observations: 84

Q-statistic probabilities adjusted for 2ARMA terms

\begin{tabular}{|c|c|c|c|c|c|}
\hline Autocorrelation & Partial Correlation & $A C$ & PAC & Q-Stat & Prob... \\
\hline 11 & 11 & $1-0.01 \ldots$ & $-0.01 \ldots$ & 0.0164 & \\
\hline 1 d 1 & 1 d & $2-0.08 \ldots$ & $-0.08 \ldots$ & 0.6127 & \\
\hline ו口 & ו口 & $\begin{array}{ll}3 & 0.132\end{array}$ & 0.131 & 2.1738 & 0.140 \\
\hline 딘 1 & เ & $4-0.15 \ldots$ & $-0.16 \ldots$ & 4.2870 & 0.117 \\
\hline & 1 & $\begin{array}{ll}5 & 0.007\end{array}$ & 0.033 & 4.2921 & 0.232 \\
\hline & 14 & $\begin{array}{ll}6 & 0.016\end{array}$ & $-0.03 \ldots$ & 4.3169 & 0.365 \\
\hline & 1 & $7-0.01 \ldots$ & 0.030 & 4.3448 & 0.501 \\
\hline 1 1 1 & 1 & $8-0.09 \ldots$ & $-0.13 \ldots$ & 5.1693 & 0.522 \\
\hline 11 & & $9-0.01 \ldots$ & $-0.00 \ldots$ & 5.1939 & 0.636 \\
\hline ים & 10 & $1 \ldots \quad 0.125$ & 0.106 & 6.7245 & 0.567 \\
\hline 101 & 101 & $1 \ldots \quad 0.063$ & 0.094 & 7.1152 & 0.625 \\
\hline 101 & 10 & $1 \ldots \quad 0.068$ & 0.059 & 7.5854 & 0.669 \\
\hline
\end{tabular}

As it can be seen from Figure 9, the autocorrelation coefficients have small values and are not statistically significant. Since one of the parameters in front of the factors 
can be considered statistically significant, it can be interpreted. From the obtained results, the following two conclusions can be made:

1. The levels of EONIA did not have a statically significant impact on the yield on the UK long-term government bonds.

2. At fixed rates of EONIA each month the interest rate on the long-term securities of the UK government is expected to decrease by 0,025173 p.p.

The aggregated results from the constructed econometric models for the non-Euro area EU Member States showed that between $95 \%$ and $98,5 \%$ of the changes in the yield of the government bonds can be explained by the changes in the EONIA levels and over time. The results also showed that at EONIA fixed rates the yield on the long-term government bonds can drop from -0,025to -0,068 p.p. monthly. The summarized results are shown in Table 10.

Table 10. Summarized results from the constructed econometric models for the nonEuro area EU Member States (in no particular order)

\begin{tabular}{|l|l|l|l|l|}
\hline $\begin{array}{l}\text { Country/ } \\
\text { Criteria }\end{array}$ & $\begin{array}{l}\text { \% from the } \\
\text { changes in the } \\
\text { government } \\
\text { bond yields, } \\
\text { explained by the } \\
\text { EONIA and the } \\
\text { time }\end{array}$ & $\begin{array}{l}\text { Statistically } \\
\text { significant of the } \\
\text { impact of } \\
\text { Base Interest } \\
\text { Rate/EONIA }\end{array}$ & $\begin{array}{l}\text { Statistically } \\
\text { significant } \\
\text { impact of } \\
\text { time }\end{array}$ & $\begin{array}{l}\text { At Base Interest } \\
\text { Rate/EONIA fixed } \\
\text { rates every month } \\
\text { government } \\
\text { bond aields are } \\
\text { expected to decline } \\
\text { by (p.p.) }\end{array}$ \\
\hline Bulgaria & $98,5 \%$ & YES & YES & $-0,042758$ \\
\hline $\begin{array}{l}\text { United } \\
\text { Kingdom }\end{array}$ & $95 \%$ & NO & YES & $-0,025173$ \\
\hline Denmark & $97 \%$ & NO & YES & $-0,033975$ \\
\hline Poland & $97,9 \%$ & NO & YES & $-0,041581$ \\
\hline Romania & $97 \%$ & NO & YES & $-0,067108$ \\
\hline Hungary & $97 \%$ & NO & YES & $-0,068021$ \\
\hline Croatia & $97 \%$ & NO & YES & $-0,042687$ \\
\hline $\begin{array}{l}\text { Czech } \\
\text { Republic }\end{array}$ & $98 \%$ & NO & YES & $-0,049697$ \\
\hline Sweden & $97 \%$ & NO & YES & $-0,030479$ \\
\hline
\end{tabular}

Source: own calculations

\section{Conclusion}

Given that the pass through of the monetary policy decisions on the real economy takes time, the full effects of the unconventional measures on the macroeconomic conditions have not yet fully materialized. In this regard, Gambacorta, Hofmann and Peersman (2012) conclude that it is challenging to find an appropriate econometric model to analyze the macroeconomic effects of central banks' measures aimed at 
increasing their balance sheets in times of crisis when the interest rates reach the zero lower bound ${ }^{7}$.

However, the adjustment of financial conditions, through which the transmission mechanism of monetary policy operates, gives encouraging signals. For example, as of June 2014, there is a trend of a significant fall in the 10-year sovereign bond yields in the Euro area, while the Euro area banks' lending rates to non-financial corporations are declining. The ECB reported improvement in lending conditions and growth in demand for new loans in all categories, which is in line with expectations for recovery of the credit growth in the Euro area ${ }^{8}$.

Regarding the statistical analysis of the impact of key central bank interest rates changes on the government bond yields of the non-Euro area EU Member States the following conclusions can be drawn: in some countries, changes in the key interest rates and the time have a statistically significant impact on the yields on the longterm government securities; in other countries - changes in the key interest rates and the time do not have a huge impact.

For the non-Euro are EU Member States, 1 p.p. increase in the interest rates would lead to a change in yields on the long-term government securities in the range of 0,068 to $-0,025$ p.p. Only in Bulgaria at fixed levels of the Base Interest Rate, each month the interest rate on the long-term government securities is expected to decrease by 0,04 p.p. In addition, it can be said that in Bulgaria the Base Interest Rate and time have a statistically significant impact.

\section{References:}

Cristea, M., Thalassinos, I.E. 2016. Private Pension Plans: An Important Component of the Financial Market. International Journal of Economics and Business Administration, 4(1), 110-115.

ECB, 2017. The euro area bank lending survey. European Central Bank, Frankfurt am Main, July 2017, available at:

https://www.ecb.europa.eu/stats/pdf/ecb.blssurvey2017q2.en.pdf?ae15d875c87cbc4d6 0432ec0c1a79800.

ECB, 2010. Unconventional monetary policy and the Great Recession. Estimating the impact of a compression in the yield spread at the zero lower bound. ECB Working Paper Series №1258, European Central Bank, Frankfurt am Main, October.

\footnotetext{
${ }^{7}$ Gambacorta, L., Hofmann, B., Peersman, G. 2012. The Effectiveness of Unconventional Monetary Policy at the Zero Lower Bound: A Cross-Country Analysis, BIS Working Papers №384, Bank of International Settlements, August, $p$. 1

${ }^{8}$ ECB, The euro area bank lending survey, Second quarter of 2017, July 2017, available at: https://www.ecb.europa.eu/stats/pdflecb.blssurvey2017q2.en.pdf?ae15d875c87cbc4d60432e c0cla79800
} 
Gambacorta, L., Marques-Ibanez, D. 2011. The Bank Lending Channel Lessons from the Crisis. ECB Working Paper Series №1335, European Central Bank, Frankfurt am Main, May.

Gambacorta, L., Hofmann, B., Peersman, G. 2012. The Effectiveness of Unconventional Monetary Policy at the Zero Lower Bound: A Cross-Country Analysis. BIS Working Papers №384, Bank of International Settlements, August, p. 1.

Lambert, F. and Ueda, K. 2014. The Effects of Unconventional Monetary Policies on Bank Soundness. IMF Working Papers №WP/14/152, International Monetary Fund, Washington D.C., August.

Mishev, G., Goev, V. 2010. Statistical analysis of time series. Avangard Prima, Sofia.

Thalassinos, I.E., Pintea, M., Raţiu, I.P. 2015a. The Recent Financial Crisis and Its Impact on the Performance Indicators of Selected Countries during the Crisis Period: A Reply. International Journal of Economics and Business Administration, 3(1), 3-20.

Thalassinos, I.E., Stamatopoulos, D.T. and Thalassinos, E.P. 2015b. The European Sovereign Debt Crisis and the Role of Credit Swaps. Chapter book in The WSPC Handbook of Futures Markets (eds) W. T. Ziemba and A.G. Malliaris, in memory of Late Milton Miller (Nobel 1990) World Scientific Handbook in Financial Economic Series Vol. 5, Chapter 20, pp. 605-639, ISBN: 978-981-4566-91-9, (doi:10.1142/9789814566926_0020).

Thalassinos, I.E. and Dafnos, G. 2015. EMU and the process of European integration: Southern Europe's economic challenges and the need for revisiting EMU's institutional framework. Chapter book in Societies in Transition: Economic, Political and Security Transformations in Contemporary Europe, 15-37, Springer International Publishing, DOI: 10.1007/978-3-319-13814-5_2. 16

Trifonova, S., Atanasov, A., Kolev, S. 2017. The Unconventional Monetary Policy of the World's Leading Central Banks and its Effects on Developed and Developing Countries, including Bulgaria. Collective monograph, Eudemonia Production, Sofia.

Veltchkova, N. 1981. Statistical methods for studying and forecasting the development of socio-economic phenomena. Science and Art, Sofia. 